\title{
6 Teaching with feminist values: A dialogical narrative analysis of gender studies educator narratives
}

\author{
Jennifer Branlat
}

\section{Gender studies education in a transnational perspective}

This chapter explores the ways in which Gender Studies educators in Norway and Japan position themselves in educating their students. With a curriculum that leads students to examine critically the complex web of gender and its intersections with sexuality, race, power relations, marginalisation and coloniality, both teacher and student may be naturally led to reflections on inequalities within the institution of higher education itself. Indeed, teaching in higher education takes place within an institutional context that has traditionally excluded women and their histories from the realm of what constitutes 'legitimate knowledge.' The overarching question I ask is the following: How do Gender Studies educators in Norway and Japan situate and position themselves pedagogically within the discursive landscape surrounding Gender Studies as it exists in the academy today? To what extent is there room for a transnational 'we' in Gender Studies education that might benefit from collective pedagogical strategies? What is to be gained by examining Gender Studies education in Norway and Japan in a cross-cultural perspective?

This study is exploratory in the sense that there is no well-defined body of scholarly literature on Gender Studies pedagogy in either Japan or Norway. In addition, proceeding with numerous uncertainties about the extent to which cultural distinctions effect educator positionings, I found it fitting to use a method unobtrusive enough to allow me to listen for influences and possible connections between teaching practice and feminist theory. Arthur Frank (2012) borrows from Bakhtin's concept of 'polyphony' to show how one's voice is never entirely one's own, but instead is rife with 'the voices of specific others' (p. 3). In this chapter, I analyse four narratives by Gender Studies educators (two from Norway, two from Japan) and use the term 'voice' to signal moments where the listener - in this case a fellow teacher and researcher - can perceive such echoes most clearly.

Gender Studies - formerly 'Women's Studies' - in both countries became institutionalised in the wake of second wave feminism, yet the processes leading to the legitimisation of the field over the years have been quite different. The same can be said for other factors - namely, the place of feminism 
within Norwegian and Japanese academic institutions, co-educational versus segregated learning environments, the culture of the workforce students are prepared for and the increasing internationalisation of higher education. All of these contextual elements and more have the potential to influence how educators position themselves in their classrooms. Most importantly, an exploration of these different positionings may tell us more about the possibility of transnational cooperation. Is there a 'we' to be found among Gender Studies educators in Norway and Japan? It is my hope that this exploratory comparative approach will also serve as the basis for future educational collaboration between the two countries. As a backdrop for further analysis, I will in the following section review literature on pedagogy in higher education to bring out differences in the Norwegian and Japanese contexts.

\section{Pedagogy, feminism and the role of the educator in higher ed}

'Pedagogy' is a term more widely used than ever before in the context of higher education research literature. It has been defined by Stommel and Morris (2018), scholars and critical pedagogy educators as the bigger picture of teaching:

Pedagogy is praxis, insistently perched at the intersection between the philosophy and the practice of teaching. When teachers talk about teaching, [they] are not necessarily doing pedagogical work, and not every teaching method constitutes a pedagogy. Rather, pedagogy necessarily involves recursive, second-order, meta-level work. Teachers teach; pedagogues teach while also actively investigating teaching and learning. (paragraph 5)

It is no longer limited to the field of educational science alone. ${ }^{1}$ Concerns for pedagogy have gradually come to find a place within many fields and often recognise the specificity of disciplinary knowledge and adapted teaching practices (see, e.g., Chick et al., 2012; Land et al., 2008). This has occurred in higher education institutions all over the world as different strands of pedagogy have emerged. Paolo Freire's model of critical pedagogy, for example, questions traditional modes of knowledge transmission and advocates for a shift away from what is known as the 'banking model' of education whereby students are seen as passive recipients of knowledge (1970). The practice of critical pedagogy has led to more active and discipline-specific ways of engaging students by promoting the value of questioning traditional models of knowledge transmission.

In Japan, however, it has been quite rare to discuss the notion of 'pedagogy' in higher education. It is much more common to do so at the middle school and high school levels. According to Japanese sociologist and well-known feminist Chizuko Ueno, critical and feminist pedagogy's 
distance from the disciplining space of higher education can be explained in the following way based on her own experience:

The method that I used [in my classroom teaching] was a Western-style teaching method based on the principle of efficiency. It is a method that allows students, from beginner to advanced-levels, to read an enormous amount of literature in accordance with the context of the course, so that they will be able to make international-level arguments in a short period of time. In Women's Studies, which is supposed to be free of efficiency and productivity, it is a dilemma to prioritise efficiency. As a result, the distance between professionals and amateurs [in Women's Studies] has become wider and wider. (1999, [my translation])

Ueno's words reflect an understanding of the university as a professionalising space dedicated to training students as researchers adept in scholarly debates and competitive as professionals of Women's Studies in a maledominated academic job market. ${ }^{2}$ As a result, pedagogy in Japanese higher education, Women's/Gender Studies included, has not been a primary concern.

With higher education's institutional focus on the end result of teaching internationally competitive researchers - attention is drawn away from the effective pedagogical practices of teachers. This is also exacerbated by the fact that research is often more highly valued than teaching. Much less scholarly attention has been devoted to what Schulman (1987) calls the 'wisdom of practice' - that is, the knowledge that guides the actions of skilled teachers (p. 11). He is particularly interested in what might be considered the 'art' of teaching or the ways in which teachers are guided by or manage ideas within classroom space. Very seldom do colleagues have the opportunity to bear witness to each other's wisdom in action since there is an obvious ' $\mathrm{I}$ ' singular in the act of university teaching, resulting in a lost opportunity: Or,...the best creations of its practitioners are lost to both contemporary and future peers' (Schulman, 1987, p. 11). In Women's/ Gender Studies, Schulman's 'wisdom of practice' has primarily been documented in the literature on feminist pedagogy emerging from an Anglo-American context.

\section{Speaking with educator narratives: A dialogical narrative approach}

The pedagogy narratives presented in this study are set into dialogue with one another using Arthur Frank's Dialogical Narrative Approach (DNA) (Frank, 2005; 2012). The central role that narratives play in this study is underscored by Jerome Bruner's (2003) claim that autobiographical narration in its diverse forms 'should be viewed as a set of procedures for "life making"' (p. 692). Bruner questions what meaning-making we engage in 
when we 'construct ourselves autobiographically,' asking how that process may reflect a constructivist approach to narratives as quintessentially 'interpretive' events rather than a verifiable transcription of what actually happened. In this study, particular consideration must be given to possible differences in the Norwegian and Japanese contexts:

Indeed, one important way of characterizing a culture is by the narrative models it makes available for describing the course of a life. And the tool kit of any culture is replete not only with a stock of canonical life narratives... but with combinable formal constituents from which its members can construct their own life narratives: canonical stances and circumstances, as it were. (Bruner, 2003, p. 694)

Frank further claims that individuals have finite means at their disposition 'stability of narrative resources' $(2012$, p. 5) - but that these never fix our identities into stable creations. DNA asks of the researcher that she respect five 'commitments' in approaching human stories. The first commitment involves acknowledging that the notions of 'voice' and 'story' are never the pure and individual forms of expression we believe them to be. An individual's voice exists rather as a patchwork of previously verbalised fragments, a 'dialogue between voices' (Frank, 2012, p. 3). It is up to the researcher to discern the presence and tease out the relationship between these different voices rather than construct a static, 'objectified image.' In this light, the researcher's role is that of a careful listener. Thus, my analysis teases out the multiple voices interviewees use in narrating their experiences of teaching in the Gender Studies classroom.

Fieldwork was conducted in Norway from February 2019 to October 2020 at the Center for Gender Research of a prominent state-funded research university. Although the Center does not currently have a BA program, it does offer a one-year program, as well as $\mathrm{MA}$ and $\mathrm{PhD}$ programs in Gender Equality and Diversity. The MA program, which is taught primarily in Norwegian, attracts students from rural and urban areas with diverse disciplinary backgrounds and typically enrols between 7 and 15 students per year. Faculty teaching in these programs noted a steady uptick in recent years' enrolment, however, which they attribute to the change in the program's name from 'Gender Studies' to 'Gender Equality and Diversity.' The new name reflects current societal ways of discussing themes related to gender, making it more appealing to students.

I interviewed a total of ten educators, six from Norway and four from Japan. Informants reflected different generations (four senior teaching faculty in their 60s, two in their 50s, three in their 40s, and one in her late 30s - all identify as women) and diverse disciplinary backgrounds (sociology, literature, anthropology and rural studies). My position in this study was that of a researcher, teacher and colleague to my informants. This chapter is part of a larger study on teaching and learning in Gender Studies that involves both 
students and teachers in Norway. Planned fieldwork in Japan (spring 2020) was interrupted by the COVID-19 pandemic, which shifted data collection from a face-to-face to an online mode. I recruited four educators (all professors, all women) through my professional network and through subsequent snowballing from Gender Studies programs at one women's university and one co-educational university in the Tokyo area. The four interviews presented in this chapter were all conducted in English and were selected based on my interest in: 1) Presenting an equal number of Japanese and Norwegian interviewees, 2) reflecting a diversity of educator positions and 3) limiting the number so that the interviewee's stories speak for themselves to the greatest degree possible.

\section{Life experiences and disciplinary teaching}

This first story was told by Noriko, a senior professor at a women's university in Japan. After completing her postgraduate studies and cultivating a successful career abroad, Noriko returned to Japan in 2010, motivated by the sense that she had much to offer the highly motivated women students at the women's university where she currently works. In our interview, Noriko talked about her initial contact with the discipline of Women's Studies as a 'coincidence, a pure accident,' but one which allowed her to subsequently engage in deep meaning-making processes about her own family life:

I grew up in a family where my father did most of the housework and childcare. Constantly throughout my childhood, I asked myself why my family was so different from other families in Japan. Because at the time moms were doing the cooking and other domestic tasks. In my family it was always my dad who did them. My mother never really participated in domestic tasks: Childcare, housework, cooking and cleaning. I grew up with this big question in my head that was never really answered until I went to university and took courses in Women's Studies and family sociology. So that was a very, not just intellectually, but personally, stimulating experience for me, to have finally found my answer...not one but many answers.

Here, Noriko invests the discipline of Women's Studies with personal meaning by talking about how it provided 'not one but many answers' to the dissonance she experienced early on between gender roles in her family and those of Japanese society in the 1950s. She narrates her entry into the discipline with an introspective voice, representing it as the end of a quest - the arriving at an explanatory framework for her earlier lived experience of difference. Her use of the reflexive tense in 'I asked myself' and the way in which she suggests that the burning question was 'in [her] head' locate the pursuit as an interior one, unable to find an outlet in other 'objective facts-based courses': 


\section{Jennifer Branlat}

I couldn't really relate to the content of 'objective' facts courses like math or Spanish, and therefore couldn't get excited about learning. I received good grades, but that's because I studied hard, it's not because I was truly motivated to learn. When I first took family sociology or sociology of women, I was really inspired by this professor who was teaching the course. She was in her late 40s or something. She often talked about her own family, her own upbringing, and her own personal kinds of issues, not all of which I could relate to simply because we came from two different cultures. I was, however, kind of inspired by the fact that she was a single mom with five kids whose husband had deserted her... [I saw] how a very tragic experience turned into very positive one. Instead of using professional vocabulary, she was really trying to explain, to use her own examples about certain concepts that otherwise may have been difficult for students to understand.

Noriko speaks very positively of her Family Sociology course and locates her eagerness to learn in the professor's willingness to share personal experiences. When I asked Noriko if she perceived her Women's Studies or 'sociology of women' courses to be unique in this way, she offered a clear distinction between 'objective' subject areas that require the memorisation of facts and the motivational and inspirational dimensions of Family Sociology - which encourages a more 'investigative' process. Noriko's use of the comparative voice shows how she sets Women's Studies against the grain of an academic tradition that values objectivity and professionalism, and formulaic 'hard' work. Her storyteller voice then enters to express awe and give shape to the professor's transformation ('how a tragic experience turned into a very positive one') in a way that mirrors Noriko's own period of uncertainty followed by understanding, which served as a catalyst for a lifelong interest in the field.

The initial encounter with the Family Sociology professor and the opening of an alternative academic world in which life experiences have a role to play in student learning led Noriko to develop her own style of teaching. When I asked Noriko if she saw this as a distinctly 'feminist' approach, she traced her genealogy back to a 'great teacher' rather than particular feminist ways of thinking:

But if you ask me if I have always been aware of feminist thinking or ideology, I would say no. I just did it in my own style, which has been influenced by many great teachers I've had in the past.

Noriko proceeds to elaborate on her own teaching style and the ways in which she approaches her students today. She draws from an understanding of her classroom as a family as she begins to narrate about her practice: 
By sharing my own experiences and my family's experiences, [students] get interested. They are always interested in our personal lives. Even without revealing too much, I can talk about, particularly in family sociology class, sibling rivalry. I talk about my daughters, my two daughters always fighting with each other [laughs], and things like that. Students can get very interested in things like that. I don't mind, I'd rather be talking about my own experiences if that helps my students to understand.

The mother's voice became most prevalent at the end of our interview when Noriko explained how she was known on the campus as the 'mother' and that she had come to see her students as her 'children.' This mother's voice carries several sub-voices and emerges as something quite complex: A caring voice that wants the students to develop through learning, an empathetic voice and an expert voice as reflected in 'a consciousness of how they might learn something' based on her more than 20 years of teaching:

I am known as 'mother of [university neighbourhood campus]'. Students come to me as a mother figure. Even the students who I only know a little bit through my regular class! They might come to me with their love problems to seek my advice. I say, ok, I can listen to you. I'm not a counsellor, so I cannot give you counselling, but... As I've gotten older, I've begun to think of my students as my own kids. What would my kids think if I taught it this way? As a parent of a student attending a university, I want my kids to be interested in the topic and want [them] to learn more. So, it's not just how I feel, but it's also the... how do you call it? An awareness or consciousness of how they might learn something. I don't know how to explain it. But I tend to think that way.

Noriko's story of her approach to teaching is presented in a long-term perspective and grounded in her own experiences with Women's Studies as a student. She finds her own experiences in the classroom more helpful than any formal notion of 'feminist pedagogy.' Her recognition that a teacher's personal experiences - narrated as stories - have an important contribution to make in the learning encounter can also be explored in dialogue with student resistance to learning, as we will see in Takako's story.

\section{Alienation and student resistance}

Takako is also a senior professor and experienced teacher whose background is in Arts. She teaches in Gender Studies but also in liberal arts courses that bring in gender perspectives. In our interview, Takako spoke from the standpoint of someone who teaches at both a women's university and a co-educational university in the same city. Takako also related her 
current identity as an educator and teaching strategies to her own experiences as a student, having attended only women's universities herself:

I went to a girl's high school and then on to a women's university and the graduate school of that same women's university. During my studies, I attended a literature club at a nearby co-ed university. That was quite a culture shock to me! I knew that when I wanted to do something, nobody would stop me among those girls. I wasn't the leader type, but I still had the awareness that I could do anything I wanted. At the co-ed university, the roles of girls and boys were strictly divided. I couldn't have been a leader there even if I had wanted to. As girls at an all-girls high school, we had to do everything on our own.

When I asked if she perceived this environment to be 'empowering,' Takako was quick to answer to the contrary: 'To me it was very natural. When somebody wanted to do something, nobody would stop her. Rather, they would encourage her and support her.' The atmosphere of the all-girls high school is voiced in terms of the lack of gendered obstacles. She describes her own response to this environment as positive in that it enabled her to take control over her life course. Takako's teacher's voice, presented in a nurturing collective voice, emphasises the continuity of past and present: 'At [a women's university] we encourage our students to do whatever they would like to do, and there is no limit. The unwritten or implicit pressures from the larger societal environment are of course still there.' Takako presents external societal pressures as potentially undermining the teacher's collective efforts, and the nurturing voice is suddenly silenced by the looming observation with which she ends her thought.

I invited Takako to talk about how she engages students in learning. She began by stressing the importance and power of representation in naturalising a particular worldview:

I think the power of representation has a stronger capacity to make us think that something is 'natural'. If you were told not to attend higher education and just get married, then you rebel; but if you're shown pictures and images over and over, it becomes natural for you to believe that this is the world. We examine traditional representations, but then I show them something that alienates, the Guerrilla Girls performance group, for example, their poster of a nude with a gorilla head [with the text, 'Do women have to be naked to get into the Met. Museum? Less than $5 \%$ of the artist[s] in the Modern Art section are women but $85 \%$ of the nudes are female.'] But anyway, I try to have them think, and each time I try to have them articulate responses [in] their own words. I don't think I teach them how to fight, but I get them to think of about the power structures of this world. 
Takako's story presents thinking and fighting as two possible feminist stances with respect to the world outside the classroom. 'Not teaching them to fight' argues against the implicit voice of a more radical feminism. This stance comes up again in the interview in a different context when Takako discusses educators' obligation not to produce radical feminists but women who can go off and work in society. The moderate feminist and teacher's voice come together to advocate for thinking over fighting as a means to work for change within a system.

Takako comes across as a reflective, experienced educator adept at navigating students' emotional thresholds. Using a strategy of alienation, a technique developed in experimental theatre to shock the audience and keep them from investing too much emotionally in a performance, she exposes her students to difficult themes. Her story reflects an awareness that it is pedagogically desirable to push students outside their comfort zones, but that such a strategy can lead to student resistance and shutdown:

A certain percentage of students who have been raised in a conservative milieu, sometimes they just can't take it. At [a women's university], the students - almost all of them are very serious. They might come to me and say: It's too hard for me to deal with this stuff. And then I give them a different question or a different perspective. I start out with the mythology and move on to art, performance art, and Disney, how women's bodies get commodified in anime these days - practices that disgustingly commodify teenage girls' bodies. When they see themselves in this representation, in their own daily life, suddenly they are like 'ooooh!' But I do want them to be aware that their own sexuality, the young female body, is fetishised, commodified and circulated in the market. They are the objects. I want them to be aware of that.

Takako explains student resistance in terms of individual student backgrounds and recognises that not all students are able to confront the images she chooses to use initially in class. With this in mind, she skilfully balances a sensitivity to students' reactions with pushing students towards the discomfort of alienation. It is only once the students are more comfortable that she proceeds with more provocative ideas and images. Her somewhat firm voice during this passage is counterbalanced by a conciliatory voice that makes room for students to work at their own comfort level. Her teacher's voice finds purpose and meaning in creating the distance that allows for critical reflection:

Through writing you can create a distance, that's the purpose of alienation. You can look at [a work of art or image] more objectively. I don't force them to judge anything, but as long as you understand something analytically then you can take it or leave it, fight for it or fight against it. That's my goal. I don't agitate them, sometimes I want to, but I don't do that. I just want them to think critically. Take a step back. 


\section{Jennifer Branlat}

Here, Takako introduces writing as a pedagogical strategy for facing the potentially disturbing nature of the curriculum and the possible flight responses it may generate. The writer's stance requires that an object be contemplated, distanced, thought and written. We conclude the conversation with a question about what Takako wants her students to carry forward from her classroom into their lives after the university: 'Have an infinite imagination. To imagine, put yourself in somebody else's shoes, or just to be able to imagine what it's like to be (an)other.'

\section{Embracing liminality}

Solveig is a professor in her 40s who entered the field of Gender Studies by chance during her master's thesis. Her motivation for working in the field lies in the fact that she has the possibility to engage in questions with a high degree of relevance for contemporary society. Solveig says, 'I feel that both in research and teaching, you can actually make a difference, maybe not a huge one, but at least we are relatively free still to form the purpose of what we do, what we teach and how we teach.' The sense of freedom and excitement she expresses is also connected to the 'openness' of the field and the enjoyment of inhabiting an 'unstable place,' which she perceives as dynamic and full of shifting perspectives - unlike the field where she pursued her BA degree.

Solveig's sense of freedom extends to the ways in which she carries out her teaching and advising, not according to checklists and objectives but according to differences in individual students: Their aims, their academic level, their ease in the academy and how much she can 'push' them. There is a distinct 'caring' voice in Solveig's story that runs counter to neoliberal discourses of branding (Gender Studies as an 'unstable field' rather than a marketable identity), competition (attending to student insecurities and needs) and the achievement of 'excellence' (hacking the 'academic game' is sometimes necessary to carry out personally meaningful projects) in higher education:

They understand the academic game that we need to play, and, in my dream world, I would not have to put a letter grade on their work. I just hate the fact that you then have to stamp or 'freeze' the work, this moment in time, finalise it when we know they will continue to develop.

In line with a feminist ethics of care, she recounts how she privileges the relational dimension of her teaching and advising, not assuming that students have the same starting points:

You realise as you get to know the students that some of them really want more safety. Some of them need something that can be transformed easily into something that can be reflected in a job title. Personally, I wouldn't want that. [For] those who can handle it, I try to get them to 
appreciate inhabiting 'an unstable place,' being more comfortable with not always knowing where they are going... I think we deal a lot with this insecurity in the beginning and then we facilitate their landing in the thesis. As long as they own their own Master's project... it's challenging for us supervisors and teachers because we have to sort of accept that we cannot steer them. We have to read up and be able to follow a very broad range of projects, very diverse projects in fact. But I think that's also a good thing that they are actually given the opportunity to land their own idea. But it's a long process.

Throughout the conversation, I perceive an oscillation between the I/we, suggesting room for both individual practices and judgements, and a collective sense of shared purpose:

We only have two years with our students, but our students really notice that we do things differently [than in other departments at the university]. We give them two advisors, we attend to their anxieties and insecurities all while pushing those who can handle it. The thing I think students have a hard time with at first is that I - and I think most of my colleagues would agree - we acknowledge that we don't have all the answers. We don't know everything [laughs]. Then they come to feel more at home in this 'vulnerability,' seeing each other as co-researchers rather than teacher/student.

Solveig's story establishes the contours of her identity with a distinctly feminist voice with its references to care, co-production and the destabilisation of the student/teacher hierarchy. She does not explicitly mention her strategies or those of her colleagues as belonging to 'feminist pedagogy,' but at the very least, her identity as a teacher emerges against an institutional context that does not place value on notions like 'trust,' which she sees as essential to the completion of an MA thesis:

As long as [the students] trust that [the faculty] can oversee it in a way that makes them comfortable. And as long as we are not expecting them to have everything settled in advance. I think that's also part of what's going on now in the second semester when they start developing their Master's project. It's a lot of active work from our side, I think, in making them understand that now we're not assessing your work. It's a work-in- progress which forms a tool for collaboration - that's new for some of them also.

\section{Finding a home in activism}

The next story is told by Astrid, a junior professor who, like Noriko, spent time abroad before returning to Norway. She sees herself has a highly 
committed feminist academic who is part of a research group on racism. Astrid's approach to teaching is grounded in an awareness, like Takako's, that Gender Studies asks students to confront uncomfortable realities about themselves, their families and the society in which they live and will develop their careers. She, too, finds that this can be problematic in classroom practice. Astrid started out by stating her own relationship to feminism:

I had some very solidarity-based idea[s] about feminism as being relevant outside of myself; it felt like it fit into this idea of me wanting to save the world. Then after taking classes [abroad], it all became very personal for me. I think they used to talk about Gender Studies as putting on a whole new way of seeing the world - a new pair of glasses that you can never ever take off again, even to watch movies.

Astrid explains that her initial entry into feminism was motivated by the material conditions, injustices and inequalities that she saw operating outside her home country. Later she had the experience of being both a student and teacher in the global south where she began to deeply question the (theoretical) centrality of Western feminism, claiming 'it all of the sudden became very personal for me.' By drawing from codes of social justice ('solidarity' and 'saving the world'), Astrid recognises the potential in feminism to work to solve societal problems. At the same time, she sees the development of feminist insight as irreversible. She continues to narrate her own coming into the discipline in an introspective voice using the metaphor of 'finding a home':

I had this idea of myself being a feminist academic with no disciplinary home, and then working outside Gender Studies you realise that people [in the academy/university] invest great meaning in the theories and methods you use and how you identify yourself. What's unique in Gender Studies is the possibility of finding a home.

Astrid sets her first-person feminist narrative against university departments that are perceived as operating according to a different set of values and established practices. By suggesting that an identification with particular theories and methods is a key part of academic life elsewhere outside of Gender Studies, Astrid is carving out a unique space for an interdisciplinary 'home' for Gender Studies and feminist academics. She explains this further, switching to a collective 'we':

The idea of having a home. It's like a collection of people who come from many different places but who aren't puritan about one's disciplinary 'traditions.' We're doing this interdisciplinary work and 
it's overtly political and we want to change something. There's something wrong in the world and we want to do something about it.

Astrid's story about what she is trying to accomplish in the classroom points to the fact that she desires a politically engaged disciplinary home. Her story resonates with Noriko's story of acquiring a novel means to understand one's own life. Both found that the lens of gender relations helped make sense of their lives up to that point.

We get young adults to take experiences that they have and extrapolate [from] them, abstract them and say there is something in the world, a different way of speaking about these experiences that isn't just about me and my relationship to another person or my family. To theorise injustice, I guess.

When I asked Astrid about her students in Gender Studies, she was quick to point out their ability to 'speak the language' and do things in an expected academic manner:

I meet these students that are theoretically fluent - they can speak the language, they can do the things and say the things and then when I push them on applying it to something that is proximal to themselves or their own communities, they can't. It falls apart. I'm currently at this stage where I'm saying, 'What do I do?'

Her story's activist voice makes salient the difference between theoretical understandings that allow students to discuss and manipulate ideas at a safe distance as opposed to the real-world confrontation of privilege or injustice. Her question about how she can manage to get students to examine issues that concern them directly is met with the rhetorical question, 'What do I do?' that doesn't seem to have an immediate or obvious answer. The next part of her story suggests that to a certain extent, she expects Gender Studies education to be difficult since the field should respect certain values. This requires an authoritative presence:

In the classroom, I'm strict about what you can say and what you cannot say, and I'll respond quickly if something is said that I don't think is ok [e.g. comments that marginalised students might find offensive]. Part of it is control, but there is also something...I don't think we should be comfortable. I know that we are working with things that are personal and we have to dig in our own lives, our own families and histories, our own bodies and our own minds and sexualities. That stuff is hard. That's one way that I think the feminisms we have in our classrooms should be hard, the learning that we want to happen. But it should also be hard in terms of confronting one's own privilege. 
The questions and difficulties that Astrid's activist voice raises are not connected to specific ways of approaching students beyond confrontation. Elsewhere in the interview, Astrid says she accepts that students will sometimes leave her classroom angry or frustrated. Her story is narrated in the second-person ('what you can and cannot say'), which comes across as authoritative but also distances her from that position. The subsequent slippage to the first-person plural when she discusses comfort and feelings of safety suggests that she sees herself as part of this process as well. She speaks from a feminist voice when she talks about the necessity of confronting privilege, borrowing codes of struggle and confrontation from feminist discourse.

We do a lot of 'safe' teaching in Norway. I say 'safe' in my teaching portfolio, and I say that I want people to be 'safe' in my classroom, but I also want them to be feminist and anti-racist spaces that aren't safe for privilege. In retrospect I can say that when I was uncomfortable, I learned. For me and people like me in that classroom, we shouldn't be safe. We are safe everywhere else. It sucks to be a woman sometimes, but when you are a (...) woman in Norway, you are mostly safe [from harm] and you benefit from diversity and gender balance projects. If I'm not safe in my own classroom, if I go out feeling uncomfortable, that's ok.

Astrid introduces the notion of safety by using vocabulary from the field of teaching and learning. While, on the one hand, she recognises that 'safe' is a buzz word in the discourse of teaching and learning, on the other, she states that such safety should not be extended to 'privilege.' She recognises the need from an institutional standpoint to demonstrate that her classroom is 'safe,' but she suggests that the concept cannot hold all possible configurations of protection simultaneously. In a moment of shifting subject positions, Astrid rationalises the construction of a potentially unsafe classroom as a tool to destabilise privilege from feminist and anti-racist points of view. What is interesting is the way that she sees a lack of safety being extended to her own self as the teacher of such a classroom.

\section{Gender studies educators: Feminist values and unbound learning spaces}

The four educator narratives presented here show that feminist values substantially inform the ways in which Noriko, Takako, Astrid and Solveig position themselves in their Gender Studies classrooms and make sense of their identity as educators. One of the most striking aspects of the stories concerns the storytellers' unbound notions of learning space. There is no mention of lecture hall or physical classroom space. The student's own self becomes one of the primary entry points into learning processes. Noriko uses her own life experiences, which she brings to life in story form (as 
opposed to using 'dry facts' from textbooks), to illustrate the relevance of gender research and provide possible points of connection to her female students' own lives. She also finds validation in making space for a motherly voice within the university - perhaps due to the unique context of a women's university - that responds with care to her students' dilemmas and problems outside the classroom. In Takako's story, she defends a pedagogical practice grounded in defamiliarisation techniques, but claims that such strategies depend on a sensitivity for students' emotional thresholds. Astrid's activist voice describes her attempts to politicise the classroom space and acknowledges the difficulties in doing so. Finally, Solveig's story represents a clear recognition of Gender Studies as an open field where teaching and advising are best carried out, in line with feminist alternatives to neoliberal thought (see, e.g., Connell, 2019), with care, responsiveness and vulnerability that help students develop a researcher identity.

The four educators presented here position themselves as feminists in that their pedagogical practices deviate from what can be considered the neoliberal 'norm' in higher education. None of them clearly mention 'feminist pedagogy' as an explicit influence, but this may be due to the absence of feminist and critical pedagogies from teacher training programs or to different cultural meanings attached to 'feminism.' 'Feminist pedagogy,' a term that can be traced back to the 1980s and early 1990s, reflects the claim that Women's and Gender Studies classrooms represent an exception to 'traditional' 3 ways of teaching. In Norway, the term 'feminist pedagogy' has not been as widely used as in the Anglo-American context to describe the praxis of feminist educators. This may be due to the fact that what is recognized as 'feminist' doesn't find a similar contrast in the Norwegian education system which has long traditions emphasizing gender equality and the value of 'sameness.' It may also be related to the visible presence and acceptance of academic feminism in Norway.

The idea of 'feminist pedagogy' also suggests that feminist values can open up for novel ways of teaching in line with 'what' we teach in Women's and Gender Studies (hooks, 1994). It is not clear, however, the extent to which these are individual strategies informed by the teacher's own disciplinary background and previous education experiences or whether there is some common ground to be discerned.

One might argue that it is risky to use the term 'feminist pedagogy' in a transnational study, given that the concept is not explicitly used in either Japan or Norway, nor is it covered in university pedagogical training programmes. There has even been significant resistance as to the possibility of feminist pedagogy in Gender Studies departments as they exist today in Japanese higher education, and Ueno (1999) warns that 'educating in a feminist way is not the same as educating in feminist theory':

[I]t has not always been easy even for many liberal educators to make visible and explicitly problematise the gender norms that pervade the 
reality of 'school,' a hierarchical space. In any case, it is a contradictory practice for teachers, who are in absolute power, to educate for 'liberation' in a system where [students] cannot choose [what constitutes] 'school,' 'classroom,' or 'homeroom.' (p. 84)

Ueno goes on to show the ever-widening divide at the turn of the 21st century between grassroots women's movements, which took as their point of departure the experiences of everyday women, and academic Women's Studies: 'Women's Studies can no longer start with a simple "let's talk about our experiences." [But] [w]e have to start by learning the language of experience.... In a sense, people without experience to refer to have entered Women's Studies' (p. 86). In this way, an authentic feminist pedagogy, with its consciousness-raising and analysis of women's lived experiences, is more at home among more democratic grassroots movements than it is in higher education.

In contexts where feminist pedagogy has been applied, educators have used it as a tool to raise consciousness about the ways in which inequalities are reflected and reproduced in educational settings and institutions themselves. Feminist educators often try to open up an alternative classroom space to counter the 'messages [that] are relayed to students about the relative power positions of different groups and individuals; and about the subjects and aspects of those subjects which are deemed appropriate for them to study' (Murphy, 2008, p. 28). Further, feminist pedagogy at a basic level promotes an awareness of social axes of difference (e.g., race, class, sexuality and ability) and the ways in which they structure individual experiences and opportunities in higher education. Murphy (2008) points out some of feminist pedagogy's key features ${ }^{4}$ that emerge in the research literature: Breakdown of traditional classroom hierarchies (destabilisation of teacher/student binary), focus on student transformation, development of a critical consciousness, awareness of the relationship between ideology, culture, power and subjectivity, classroom conceptualised as a political space with power relations that reflect those of the society at large, awareness of implicit learning about gender that takes place outside the classroom, democratisation and student voice (p. 93). In addition to this list, we might add: A valuing of the relational dimensions of teaching (Hooks, 1994), a recognition of the politics of knowledge production in higher education, and an intersectional approach to understanding genderbased oppression. In Hooks' (1994) view, it is an individual educator's task to reflect on and develop a teaching practice that brings in any combination of these elements, while remaining open to others.

These stories are to some degree individual (based on educator's own lived experiences) and field-specific (related to educator's academic specialisation) but do not reflect strong cultural distinctions. On that account, the stories provide a basis for future research. Given the individualised nature of the stories, more research is needed to examine the extent to 
which a transnational 'we' might be possible, and how such collective strategies might be linked to learning objectives and assessment. Setting these stories in dialogue through dialogical narrative analysis allows me to present these teachers as 'unfinalized' (Frank, 2005, p. 966) and to conclude with the certainty that making these stories accessible to Gender Studies colleagues and students will ensure that they continue to take form.

\section{Notes}

1 A literature search in the database Scopus on English language publications containing the keywords 'pedagogy' and 'higher education' shows an increase from the occasional one or two entries per year in the 1980 s to a high of over 700 entries in 2020.

2 Ueno points out that the overarching goal of professionalization has led to women's studies being open to male scholars who are (more) often able to meet the unquestioned criteria of 'excellence.'

3 What is meant by 'traditional' ways of teaching remains to be explored.

4 The starting point for this enumeration is Murphy, 2008, p. 93.

\section{References}

Bruner, J.S. (2003). Making stories: Law, literature, life. Harvard University Press. Connell, R. (2019). The good university. What universities actually do and why it's time for radical change. ZED Books.

Chick, N. L., Haynie, A., \& Gurung, R. A. R. (2012). Exploring more signature pedagogies: Approaches to teaching disciplinary habits of mind. Stylus Publishing.

Frank, A.W. (2005). What is dialogical research, and why should we do it? Qualitative Health Research, 15(7), 964-974.

Frank, A.W. (2012). Practicing dialogical narrative analysis. In Holstein, J.A., \& Gubrium, J.F. (Eds.), Varieties of narrative analysis (33-52). SAGE.

Freire, P. (1970). Pedagogy of the oppressed. The Seabury Press.

Hooks, B. (1994). Teaching to transgress: Education as the practice of freedom. Routledge.

Land, R., Meyer, J. H. F., \& Smith, J. (2008). Threshold concepts within the disciplines. Sense Publishers.

Murphy, P. (2008). Defining Pedagogy. In Hall, K., Murphy, P., \& Soler, J. (Eds.). Pedagogy and practice: Culture and identities, 28-39. SAGE.

Schulman, L. (1987). Knowledge and teaching: Foundations of the new reform. Harvard Educational Review, 57(1), 1-21.

Stommel and Morris. (2018). An urgency of teachers: The work of critical digital pedagogy. Hybrid Pedagogy.

Ueno, C. (1999). Difficulties in feminist pedagogy. In Sato, M. et al. (Eds.). Gender and education. Seori-shobo. 